\title{
Invasive Streptococcal Infection Diagnosed with Group A Beta Hemolytic Streptococcus Positivity in Throat Culture
}

\author{
Boğaz Kültüründe A Grubu Beta Hemolitik Streptokok Pozitifliği ile \\ Tanı Alan Invazif Streptokok Enfeksiyonu
}

\author{
Elif Ece Eren'(iD), Nazan Dalgıç2(ID), Ferhat Sarı(iD), Uğur Girgiç'(ID) \\ ${ }^{1}$ Clinic of Pediatrics, Şişli Hamidiye Etfal Training and Research Hospital, Istanbul, Turkey \\ ${ }^{2}$ Clinic of Pediatric Infectious Diseases, Şişli Hamidiye Etfal Training and Research Hospital, Istanbul, Turkey \\ ${ }^{3}$ Clinic of Pediatric Intensive Care Unit, Mustafa Kemal University Faculty of Medicine, Hatay, Turkey
}

Cite this article as: Eren EE, Dalgıç N, Sarı F, Girgiç U. Invasive streptococcal infection diagnosed with group A beta hemolytic streptococcus positivity in throat culture. J Pediatr Inf 2021;15(3):e183-e187.

Abstract

Group A streptococcus (GAS) infections are often associated with pharyngitis, skin and soft tissue infection, but may have a variety of presentations that can lead to bacteremia, necrotizing fasciitis, and Streptococcal Toxic Shock Syndrome (STSS). Invasive GAS infections are seen most commonly in infancy and if they are not managed well, mortality is high. Therefore, they should be immediately diagnosed and treated successfully. In this study, it was aimed to report a patient admitted to our hospital complaining of high fever and rash, followed with an initial diagnosis of pneumonia and sepsis, and later diagnosed as invasive streptococcal infection. By presenting this case, we aimed to emphasize the wide range of GAS infections and their treatment properly.

Keywords: Pediatric, Streptococcus pyogenes, sepsis

\section{Introduction}

Group A streptococcus (GAS; Streptococcus pyogenes) is an aerobic Gram-positive coccus that may cause various infections (1). Although its frequency varies in different regions, it is estimated that the annual incidence of invasive GAS infection
Öz

A grubu Beta Hemolitik Streptokok (GAS) enfeksiyonları sıklıkla farenjit, cilt ve yumuşak doku enfeksiyonu ile ilişkili olmakla beraber bakteriyemi, nekrotizan fasiit ve Streptokoksik Toksik Şok Sendromu (STSS)'na kadar değiş̧ebilen geniş bir spektrumda kliniğe neden olabilir. İnvazif GAS enfeksiyonları en sık süt çocuklarında görülmektedir. STSS'lu olgular hızla tanınmalı ve tedavi başlanmalıdır, aksi halde mortal seyretmektedir. Bu makalede, hastanemize ateş ve döküntü şikâyeti ile başvuran, pnömoni ve sepsis ön tanıları ile takip edilen, izlemde invazif streptokok enfeksiyonu tanısı alan bir olgu sunarak GAS enfeksiyonlarının klinik tablosunun ne kadar geniş olabileceğini ve tedavi yönetimini vurgulamayı amaçladık.

Anahtar Kelimeler: Pediatri, Streptococcus pyogenes, sepsis

is 3 cases per 100.000 people. The incidence of invasive infection in the pediatric population is higher in patients under one year of age (2-6). GAS infections are often associated with pharyngitis, skin, and soft tissue infection, but they may have a variety of presentations leading to invasive disease. GAS infections, whether they have a local focus or not, may become

\section{Correspondence Address / Yazışma Adresi}

\section{Elif Ece Eren}

Şişli Hamidiye Etfal Eğitim ve Araştırma Hastanesi,

Çocuk Sağlığı ve Hastalıkları Kliniği,

İstanbul-Türkiye

E-mail: elifece.eren@yahoo.com 
Table 1. Streptococcal Toxic Shock Syndrome (Committee on Infectious Diseases American Academy of Pediatrics, Red Book, $31^{\text {st }}$ ed. IL: Itasca; 2018)

I. Isolation of group A Streptococcus (Streptococcus pyogenes)

A. From a normally sterile site (eg: blood, cerebrospinal fluid, peritoneal, joint, pleural, or pericardial fluid)

B. From a nonsterile site (eg: throat, sputum, vagina, open surgical wound, or superficial skin lesion)

II. Clinical signs of severity

A. Hypotension: systolic pressure $90 \mathrm{mmHg}$ or less in adults or lower than the fifth percentile for age in children $<16$ years of age and

B. Two or more of the following signs of multi-organ involvement:

- Renal impairment: creatinine concentration $177 \mu \mathrm{mol} / \mathrm{L}(2 \mathrm{mg} / \mathrm{dL})$ or greater for adults or at least 2 times the upper limit of normal for age ${ }^{a}$

- Coagulopathy: platelet count $100000 / \mathrm{mm}^{3}$ or less and/or disseminated intravascular coagulation defined by prolonged clotting times, low fibrinogen, and presence of fibrin degradation products

- Hepatic involvement: elevated alanine transaminase, aspartate transaminase, or total bilirubin concentrations at least 2 times the upper limit of normal for age ${ }^{\mathbf{b}}$

- $\quad$ Adult respiratory distress syndrome defined by acute onset of diffuse pulmonary infiltrates and hypoxemia in absence of cardiac failure or by evidence of the diffuse capillary leak

- $\quad$ A generalized erythematous macular rash that may desquamate

- $\quad$ Soft tissue necrosis, including necrotizing fasciitis or myositis, or gangrene

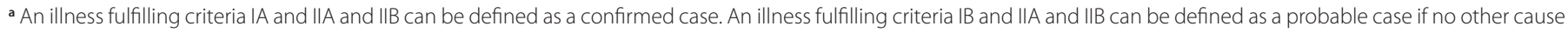
for the illness is identified. Manifestations need not be detected within the first 48 hours of illness or hospitalization.

b In patients with preexisting renal or hepatic disease, concentrations twofold, or greater over the patient's baseline.

clinically severe such as streptococcal toxic shock syndrome (STSS) or necrotizing fasciitis. Cytokines activated by superantigens and streptococcal pyrogenic exotoxins are thought to be responsible for the invasive disease (7). There is a Clinical Case Definition with several parameters for the diagnosis of invasive disease (Table 1). Case-fatality rates range from $0.2 \%$ to $25 \%$ depending on the age of the patient, presence of comorbidities, the severity of the invasive infection, and the level of health care services. However, in the presence of STSS, the mortality rate can reach up to $50 \%(2,8-10)$.

We aimed to report a patient admitted to our hospital complaining of high fever and rash, followed with an initial diagnosis of pneumonia and sepsis, and later diagnosed as invasive streptococcal infection.

\section{Case Report}

A four-and-a-half-year-old male patient was admitted to our hospital with complaints of high fever, cough, and rash which started five days ago. He had a persistent fever and then developed rash, abdominal pain, vomiting, and malaise. On initial assessment, his body temperature was $37^{\circ} \mathrm{C}$, respiratory rate was $20 / \mathrm{min}$, heart rate was $90 / \mathrm{min}$. On the physical examination, the patient had a strawberry tongue and hyperemic tonsils. There was diffused erythema called a sandpaper-like appearance on the trunk. Pastia's lines were present in the antecubital fossae. The abdomen was diffusely tender. The rest of the physical examination was normal. Laboratory study showed a White Blood Count (WBC), 10530/mm³ $(68 \%$ polymorphonuclear leucocytes); hemoglobin, $12 \mathrm{~g} / \mathrm{L}$; thrombocytes, $214.000 / \mathrm{mm}^{3}$; C-reactive protein (CRP) was $135 \mathrm{mg} / \mathrm{L}$ (0-5 mg/L), electrolytes and urinalysis were normal. The patient was consulted to the pediatric surgery department. Surgical intervention was not considered for the patient, and follow-up was recommended. A rapid strep test was performed, and it was positive. Along with the signs and symptoms, the patient was diagnosed with scarlet fever. For the treatment of scarlet fever, benzathine penicillin (Deposilin ${ }^{\circledR}$ 6.3.3 Flk) was administered to the patient intramuscularly. Then, the patient was discharged home with close follow-up. Two days later, he was brought to the emergency department with a history of high fever, oral lesions, abdominal pain, diarrhea, and rapid breathing. The patient had a septic appearance and his body temperature was $38.5^{\circ} \mathrm{C}$; respiratory rate was $30 / \mathrm{min}$; heart rate was 120 /min; blood pressure was $77 / 42 \mathrm{mmHg}$ and oxygen saturation was $90 \%$ in the room air. On physical examination, breath sounds were decreased on the base of the left lung. Blood tests revealed hemoglobin, $12 \mathrm{~g} / \mathrm{L}$; leukocytes $10450 / \mathrm{mm}^{3}$; neutrophile, $9480 / \mathrm{mm}^{3}$; platelets, $106.000 / \mathrm{mm}^{3}$, urea, $90 \mathrm{mg} / \mathrm{dl}$ ( $<43 \mathrm{mg} / \mathrm{dL}) ;$ creatinine, $0.66 \mathrm{mg} / \mathrm{dl}(0.2-0.43$ $\mathrm{mg} / \mathrm{dl}$ ); albumin, $2.4 \mathrm{~g} / \mathrm{dL}$; aspartate aminotransferase (AST)/ alanine aminotransferase (ALT), 112/58 U/L (<40 U/L); glucose, $58 \mathrm{mg} / \mathrm{dl}$; sodium (Na), $129 \mathrm{mmol} / \mathrm{L} ; \mathrm{CRP}, 423 \mathrm{mg} / \mathrm{L}$; procalcitonin, $22 \mathrm{ug} / \mathrm{L}(<0.12 \mathrm{ug} / \mathrm{L})$; triglyceride, $539 \mathrm{mg} / \mathrm{dl}(6 \mathrm{mmol} / \mathrm{L})$ and ferritin, $193 \mu \mathrm{g} / \mathrm{L}$. There was toxic granulation of polymor- 


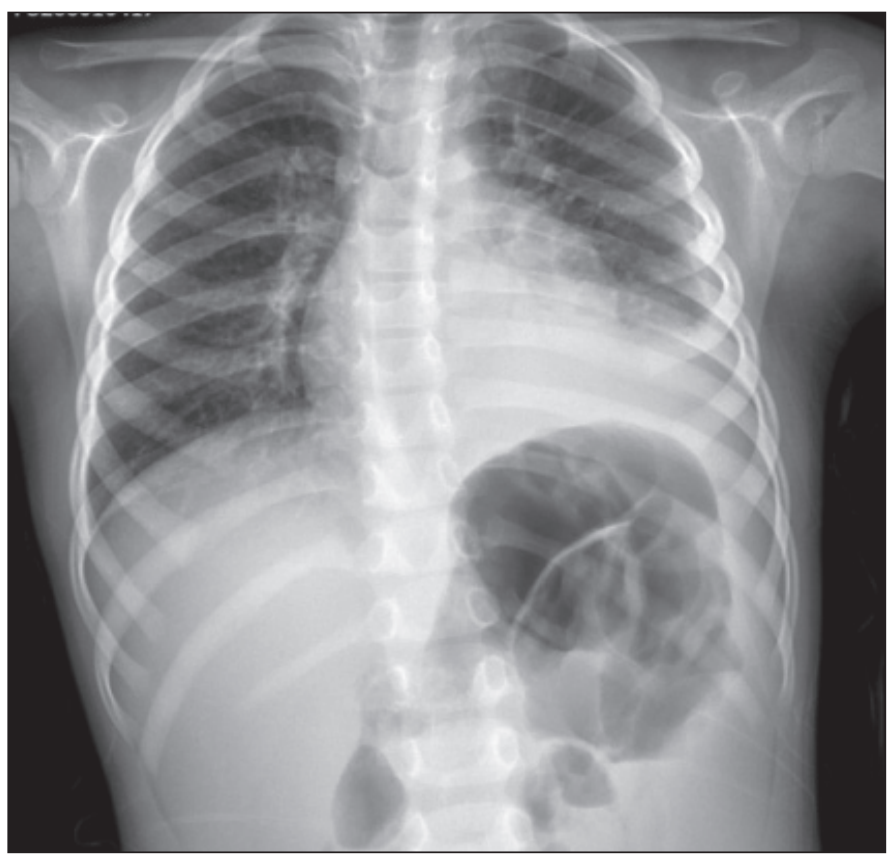

Figure 1. A chest X-Ray demonstrated consolidation in the base of the left lung (second admission).

phonuclear leukocytes and a left shift on the peripheral blood smear. A chest X-Ray demonstrated consolidation in the base of the left lung (Figure 1). Blood and urine culture samples were taken, and empirical antibiotic therapy (ceftriaxone, 80 $\mathrm{mg} / \mathrm{kg} /$ day, intravenous) was administered. Abdomen and thorax ultrasonography reported $4 \mathrm{~cm}$ free fluid in the abdomen and $5 \mathrm{~cm}$ pleural effusion in the left lung, respectively. The patient was consulted to the Pediatric Surgery Department for tube thoracoscopy. The tube could not be inserted because of the insufficient fluid drainage from the aspiration, but pleural fluid sampling was performed for microbiological and biochemical analysis. Laboratory findings of pleural fluid was leukocyte, $5000 / \mathrm{mm}^{3}$ (80\% neutrophil, $20 \%$ lymphocyte); erythrocyte, $160 / \mathrm{mm}^{3}$; protein, $3705 \mathrm{mg} / \mathrm{dl}$; glucose, $49 \mathrm{mg} / \mathrm{dl}$; lactate dehydrogenase (LDH), $6639 \mathrm{U} / \mathrm{L}$. The patient was transferred to the pediatric intensive care unit with a preliminary diagnoses of sepsis, pneumonia, parapneumonic effusion, and hemophagocytic syndrome. One day after admission, the patient developed severe sepsis and antibiotherapy was switched to vancomycin ( $60 \mathrm{mg} / \mathrm{kg} /$ day at 4 doses) and meropenem $(100 \mathrm{mg} / \mathrm{kg} /$ day at 3 doses). The patient was consulted to the pediatric hematology department to be evaluated for hemophagocytosis syndrome. Although hemophagocytosis was not considered definitely, administration of intravenous immunoglobulin (IVIG) was recommended for severe sepsis. IVIG at a dose of $1 \mathrm{~g} / \mathrm{kg} /$ day was administered to the patient. The patient with persistent high fever was consulted to the Department of Pediatric Infectious Diseases. When the patient's history and records were reviewed again, it was found that the area of consolidation in the base of the left lung was

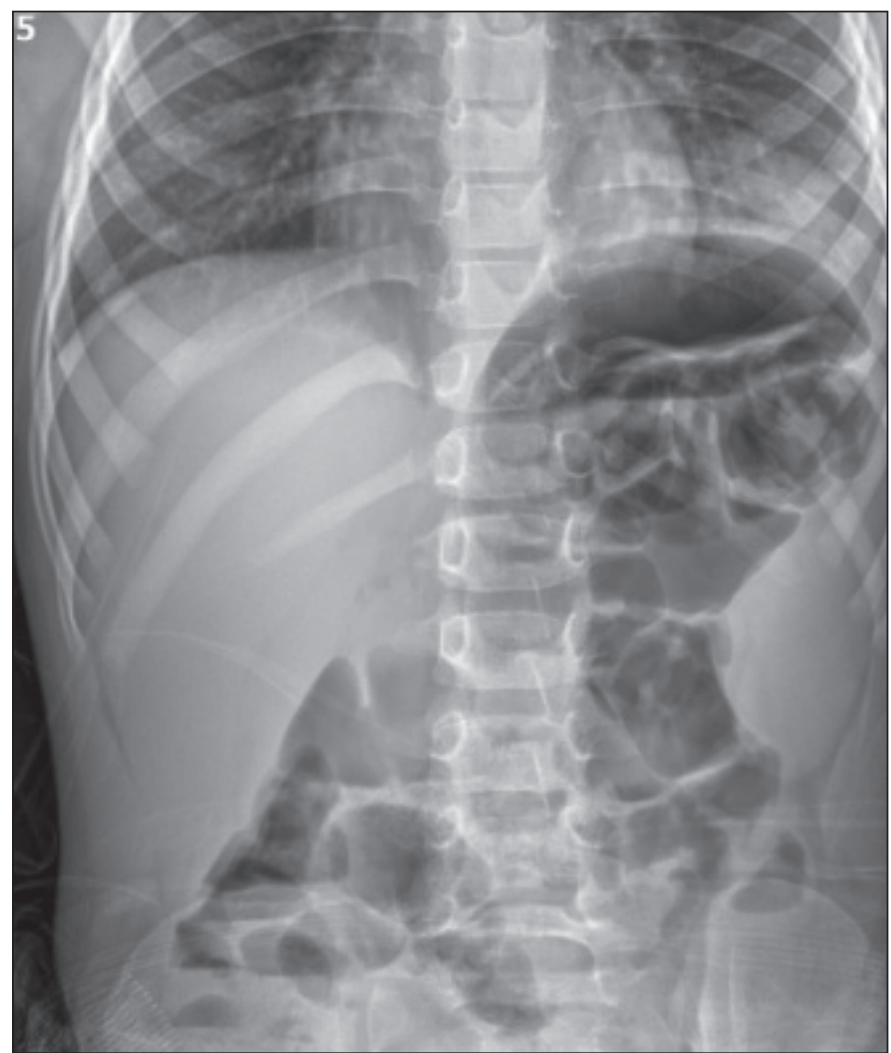

Figure 2. The area of consolidation in the base of the left lung was overlooked on abdominal X-ray (first admission).

overlooked on the abdominal X-ray due to gas in the stomach at first admission (Figure 2). This condition was associated with the poorly treated invasive streptococcal infection. Then, the patient was diagnosed with STSS, and clindamycin (30 $\mathrm{mg} / \mathrm{kg} /$ day in divided doses 3 times daily) and IVIG $(1 \mathrm{~g} / \mathrm{kg})$ was added to the treatment regimen. After 72 hours, the fever was resolved. On the fifth day of treatment, sudden respiratory distress developed. Evidence of an increase in effusion in the left lung was seen on the chest X-ray. After that, thorax CT was performed, and it showed nearly complete atelectasis due to pleural effusion of $25 \mathrm{~mm}$ in the left hemithorax. Tube thoracostomy was placed by pediatric surgery. In the follow-up, no oscillation in the thorax tube was seen, and there were septal loci on thoracic ultrasound, then the patient was consulted to pediatric surgery for video-assisted thoracoscopic surgery (VATS). With the recommendation of the pediatric surgery department, tissue plasminogen activator $(0.1 \mathrm{mg} /$ $\mathrm{kg}$; maximum, $3 \mathrm{mg} /$ day) was administered at an interval of 24 hours via the thorax tube, for three days, instead of VATS. The thorax tube was removed on the 12th day of hospitalization. No growth was seen in the body fluid cultures, and the parenteral antibiotherapy was completed in 21 days, and the patient was discharged.

Informed consent was obtained from the patient's family for the presentation of this case. 


\section{Discussion}

GAS infections can cause a variety of infections, ranging from tonsillopharyngitis, erysipelas, scarlet fever to severe infections such as pneumonia, meningitis, bacteremia, necrotizing fasciitis, and toxic shock syndrome. Invasive GAS infections are most commonly seen in infancy and unless treated adequately, there is a high mortality. (2,7-9). There are clinical diagnostic criteria adopted worldwide to ensure the diagnosis of invasive GAS infections (Table 1) (7). Among those criteria, isolation of group A Streptococcus is the main diagnostic criteria from a normally sterile or a nonsterile site. Rapid Antigen Tests (RADTs) do not have a diagnostic value for invasive diseases related to GAS. RADTs have a specificity of $\geq 95$ percent and a sensitivity that varies between 85 and 95 percent for GAS. But, the sensitivity of these RADTs is highly dependent on the level of expertise of the person performing the test, the quality of the throat swab specimen, and the selectivity of the culture method used for comparison. Our patient had group A beta-hemolytic streptococcus growth in throat culture along with RADT positivity, systemic hypotension, and renal, hepatic, skin involvement at the time of the first admission among these criteria (Table 1).

During follow-up, no growth was detected in the blood and pleural fluid cultures in our case. It might be as a result of benzathine penicillin administration at the outpatient clinic. The cough is generally not expected in pharyngitis. Even though cough, vomiting, and abdominal pain are alarming symptoms in terms of lower lobe pneumonia, the patient's diagnosis was mistaken with acute abdomen. In the literature, there is an eight-year-old male patient who was operated with a diagnosis of acute appendicitis due to similar admission with abdominal pain. On the third postoperative day, he was diagnosed with invasive GAS infection with the growth of Streptococcus pyogenes in peritoneal fluid. Also, in the article, there were another eleven patients presented whose clinical presentations were pneumonia, bacteremia without septic focus, septic arthritis,and necrotising fasciitis. Majority of the cases were in children with no underlying medical conditions. Nine patients had multi-organ failure and needed inotropic and/or vasopressor support, ten patients required mechanical ventilation. Eleven patients survived, but one patient who had trisomy 21 and congenital heart diseases died. Most children returned to almost normal neurological function (11). In another article, an STSS-like case was presented as a complication of varicella infection. Authors emphasized that toxic shock syndrome associated with staphylococcal or streptococcal skin infections secondary to varicella infection might be life-threatening (12).

Differential diagnosis of SSTS includes staphylococcal TSS, Gram-negative sepsis, meningococcemia, Streptococcus pneu- monia and Mycoplasma pneumonia infection, Kawasaki disease, and even COVID-19 multisystem inflammatory syndrome nowadays (13). All of these differential diagnoses were excluded along with the history and clinical findings of the patient, laboratory, and radiological studies. For differential diagnosis, GAS carriage should not be overlooked. Five to 21 percent of children are pharyngeal carriers of GAS. Despite the value of RADTs and throat culture in the diagnosis, neither can differentiate acute GAS pharyngitis from GAS carriage. So, RADTs should be performed in patients only with symptoms of sore throat in the absence of rhinorrhea, nasal congestion, and cough (7).

Streptococcus pyogenes is very sensitive to treatment with beta-lactams (penicillin and cephalosporins), and sensitivity tests are only required for non-beta-lactam drugs. Treatments shorter than 10 days, especially with penicillin V, for GAS pharyngitis are associated with low bacteriological eradication rates. In this sense, intramuscular benzathine penicillin $\mathrm{G}$ is a suitable treatment option. This treatment provides sufficient concentration in the blood and is beneficial for the patient's compliance, but the administration is painful. Benzathine penicillin $\mathrm{G}$ alone is not sufficient for the treatment of toxic shock syndromes. The addition of clindamycin is more effective than the use of penicillin alone in treating proven GAS infections, because clindamycin is not affected by the amount of inoculum of bacteria, and the post-antibiotic effect lasts long and inhibits protein synthesis (7). Also, IVIG may be considered as adjuvant therapy in severe cases with STSS, but data supporting IVIG usage is limited. Although IVIG can be used as $1 \mathrm{gr} /$ $\mathrm{kg}$ on the first day, and $0.5 \mathrm{~g} / \mathrm{kg}$ on the second and third days, the optimal treatment regimen is unknown (7,14-15). Our patient was given parenteral benzathine penicillin $\mathrm{G}$ initially, but parenteral treatment was insufficient due to the presence of pneumonia. Treatment of streptococcal infections with a single dose of parenteral penicillin is recommended only in tonsillopharyngitis. In this regard, it is vital to evaluate patients with careful physical examination for other possible complicated streptococcal infections and to organize their treatment properly.

In this report, we aimed to emphasize that GAS infections may have a wide range of presentation, and if not managed and treated properly high mortality is inevitable.

Informed Consent: Patient consent was obtained.

Peer-review: Externally peer-reviewed.

Author Contributions: Concept - EEE, ND; Design - EEE, ND; Supervision - ND, FS; Resources - EEE, UG; Data Collection and/or Processing - EEE, ND, FS; Analysis and/or Interpretation - EEE, ND, FS; Literature Review - EEE; Writing - EEE, ND, UG; Critical Review - ND, FS. 
Conflict of Interest: No conflict of interest was declared by the authors.

Financial Disclosure: The authors declared that this study has received no financial support.

\section{References}

1. Stevens DL. Invasive group A streptococcus infections. Clin Infect Dis 1992;14(1):2-11. [CrossRef]

2. Centers for Disease Control and Prevention. Active Bacterial Core Surveillance (ABCS). ABCS Report: group A Streptococcus, 2017, available at https://www.cdc.gov/abcs/reports-findings/survreports/ gas17.html (Accessed on November 08, 2019). [CrossRef]

3. Tapiainen $T$, Launonen $S$, Renko $M$. Invasive group a streptococcal Infections in children: a nationwide survey in Finland. Pediatr Infect Dis J 2016;35(2):123-8. [CrossRef]

4. Davies HD, McGeer A, Schwartz B. Invasive group A streptococcal infections in Ontario, Canada. Ontario Group A Streptococcal Study Group. N Engl J Med 1996;335(8):547-54. [CrossRef]

5. Nelson GE, Pondo $T$, Toews KA. epidemiology of invasive group a streptococcal Infections in the United States, 2005-2012. Clin Infect Dis 2016;63(4):478-86. [CrossRef]

6. Topkaya $A E$, Balıkcı A, Aydın F. Türkiye'de invazif streptokok enfeksiyonlarının epidemiyolojisi, klinik ve mikrobiyolojik özellikleri, 2010-2011. Mikrobiyol Bul 2014;48(1):1-13. [CrossRef]

7. Committee on Infectious Diseases American Academy of Pediatrics. Red Book: 2018 Report of the Committee on Infectious Diseases. $31^{\text {st }}$ ed. IL: Itasca; 2018. [CrossRef]
8. Megged O, Yinnon AM, Raveh D, Rudensky B, Schlesinger Y. Group A streptococcus bacteremia: comparison of adults and children in a single medical center. Clin Microbiol Infect 2006;12(2):156-62. [CrossRef]

9. Carapetis JR, Steer AC, Mulholland EK, Weber M. The global burden of group A streptococcal diseases. Lancet Infect Dis 2005;5(11):685-94. [CrossRef]

10. Cohen JF, Bertille N, Cohen R, Chalumeau M. Rapid antigen detection test for group A streptococcus in children with pharyngitis. Cochrane Database Syst Rev $2016 \mathrm{Jul}$ 4;7(7):CD010502. [CrossRef]

11. Lithgow A, Duke T, Steer A, Smeesters PR. Severe group A streptococcal infections in a pediatric intensive care unit. J Paediatr Child Health 2014;50(9):687-92. [CrossRef]

12. Aslan MT, Nalbantoğlu A, Samancı N, Balcı H, Kayıkçı A. A serious and rare complication following varicella infection; streptococcal toxic shock syndrome-like case report. J Pediatr Infect 2017;11(4):179-82. [CrossRef]

13. Whittaker E, Bamford A, Kenny J, Kaforou M, Jones $C E$, Shah $P$, et al; PIMS-TS Study Group and EUCLIDS and PERFORM Consortia. Clinical characteristics of 58 children with a pediatric Inflammatory multisystem syndrome temporally associated with SARS-CoV-2. JAMA. $2020 \mathrm{Jul}$ 21;324(3):259-69. [CrossRef]

14. Waddington CS, Snelling TL, Carapetis JR. Management of invasive group A streptococcal infections. J Infect 2014;69 Suppl1: S63-S69. [CrossRef]

15. Allen U, Moore D. Invasive group A streptococcal disease: Management and chemoprophylaxis. Paediatr Child Health 2010;15(5):295-302. [CrossRef] 